\title{
Neprilysin Overexpression Inhibits Plaque Formation But Fails to Reduce Pathogenic A $\beta$ Oligomers and Associated Cognitive Deficits in Human Amyloid Precursor Protein Transgenic Mice
}

\author{
William J. Meilandt, ${ }^{1,2}$ Moustapha Cisse, ${ }^{1,2}$ Kaitlyn Ho, ${ }^{1}$ Tiffany Wu, ${ }^{1}$ Luke A. Esposito, ${ }^{1,2}$ Kimberly Scearce-Levie, ${ }^{1,2}$ \\ Irene H. Cheng, ${ }^{1,2}$ Gui-Qiu Yu, ${ }^{1}$ and Lennart Mucke ${ }^{1,2}$ \\ ${ }^{1}$ Gladstone Institute of Neurological Disease and ${ }^{2}$ Department of Neurology, University of California, San Francisco, California 94158
}

\begin{abstract}
The accumulation of amyloid- $\beta(\mathrm{A} \beta)$ peptides in the brain of patients with Alzheimer's disease (AD) may arise from an imbalance between $A \beta$ production and clearance. Overexpression of the $A \beta$-degrading enzyme neprilysin in brains of human amyloid precursor protein (hAPP) transgenic mice decreases overall $\mathrm{A} \beta$ levels and amyloid plaque burdens. Because AD-related synaptic and cognitive deficits appear to be more closely related to $\mathrm{A} \beta$ oligomers than to plaques, it is important to determine whether increased neprilysin activity also diminishes the levels of pathogenic $A \beta$ oligomers and related neuronal deficits in vivo. To address this question, we crossed hAPP transgenic mice with neprilysin transgenic mice and analyzed their offspring. Neprilysin overexpression reduced soluble A $\beta$ levels by $50 \%$ and effectively prevented early $\mathrm{A} \beta$ deposition in the neocortex and hippocampus. However, it did not reduce levels of $\mathrm{A} \beta$ trimers and $\mathrm{A} \beta{ }^{\star} 56$ or improve deficits in spatial learning and memory. The differential effect of neprilysin on plaques and oligomers suggests that neprilysin-dependent degradation of $\mathrm{A} \beta$ affects plaques more than oligomers and that these structures may form through distinct assembly mechanisms. Neprilysin's inability to prevent learning and memory deficits in hAPP mice may be related to its inability to reduce pathogenic $A \beta$ oligomers. Reduction of $A \beta$ oligomers will likely be required for anti-A $\beta$ treatments to improve cognitive functions.
\end{abstract}

Key words: memory; hippocampus; amyloid; $\mathrm{A} \beta^{\star} 56$; water maze; premature mortality

\section{Introduction}

Alzheimer's disease (AD) is the most prevalent and costly neurodegenerative disorder (Ferri et al., 2005). Although major efforts have been made to elucidate its pathogenesis, there still are no strategies to effectively treat or prevent $\mathrm{AD}$. A key factor in $\mathrm{AD}$ pathogenesis is the amyloid- $\beta(\mathrm{A} \beta)$ peptide, which is generated through proteolytic cleavage of the amyloid precursor protein (APP) by $\beta$ - and $\gamma$-secretases (Blennow et al., 2006; Roberson and Mucke, 2006). Rare forms of autosomal dominant familial AD (FAD) have been conceptually informative as they are linked to mutations in human APP (hAPP) or components of the $\gamma$-secretase complex (presenilin 1 and presenilin 2) that increase the absolute or relative abundance of the 42 -amino acid form of

Received June 27, 2008; revised Dec. 17, 2008; accepted Dec. 29, 2008.

This work was supported by National Institutes of Health Grants AG011385 and NS041787 to L.M. and RR018928 to the J. David Gladstone Institutes. We thank M. Leissring and D. Selkoe for neprilysin transgenic mice; D. Walsh and G. Shankar for advice on dimer measurements; P. Seubert for anti-A $\beta$ antibodies; E. Koo for the CT-15 antibody; J. Palop for helpful comments on this manuscript; H. Solanoy, X. Wang, and D. Kim for technical support; G. Howard and S. Ordway for editorial review; J. Carroll for preparation of graphics; and D. McPherson and T. Hamto for administrative assistance.

Correspondence should be addressed to Lennart Mucke, Gladstone Institute of Neurological Disease, 16500 wens Street, San Francisco, CA 94158. E-mail: Imucke@gladstone.ucsf.edu.

DOI:10.1523/JNEUROSCI.2984-08.2009

Copyright $\odot 2009$ Society for Neuroscience $\quad$ 0270-6474/09/291977-10\$15.00/0
$\mathrm{A} \beta$ (A $\beta 1-42)$, which aggregates more readily and is more toxic than A $\beta 1-40$ (Blennow et al., 2006; Roberson and Mucke, 2006). Transgenic mice expressing FAD-mutant hAPP produce high levels of A $\beta 1-42$ and develop age-dependent cognitive deficits and neuropathological alterations similar to those found in $\mathrm{AD}$ patients (Kobayashi and Chen, 2005; Palop et al., 2006).

However, whether alterations in $A \beta$ production also contribute to the vast majority of $\mathrm{AD}$ cases that lack these mutations remains uncertain. An alternative mechanism of $A \beta$ accumulation in these cases may be an age-dependent deficit in $\mathrm{A} \beta$ clearance (Selkoe, 2001; Iwata et al., 2002; Caccamo et al., 2005; Iwata et al., 2005; Mueller-Steiner et al., 2006; Hellström-Lindahl et al., 2008). Several proteases degrade $A \beta$, including neprilysin (NEP) (Iwata et al., 2001; Shirotani et al., 2001; Leissring et al., 2003; Marr et al., 2003; Caccamo et al., 2005), insulin-degrading enzyme (Chesneau et al., 2000; Leissring et al., 2003; Caccamo et al., 2005), endothelin-converting enzyme (Choi et al., 2006), plasmin (Tucker et al., 2000), and cathepsin B (Mueller-Steiner et al., 2006; Gan and Mucke, 2008). Alterations in the activities of these proteases could have profound effects on $A \beta$ accumulation and $\mathrm{AD}$.

In agreement with this notion, pharmacological inactivation (Mouri et al., 2006) or genetic ablation (Huang et al., 2006; Farris et al., 2007) of NEP in hAPP mice increased total $A \beta$ levels in the 
brain and plasma, whole brain and hippocampal levels of $\mathrm{A} \beta$ dimers, $\mathrm{A} \beta$ deposition, plaque-related pathology, deficits in synaptic plasticity, and impairments in hippocampus-dependent memory. In contrast, viral vector-mediated (Marr et al., 2003; Iwata et al., 2004) or transgene-mediated (Leissring et al., 2003; Poirier et al., 2006) overexpression of NEP reduced cortical A $\beta$ levels, $\mathrm{A} \beta$ deposition, and plaque-related pathology.

Because $A \beta$-induced neuronal deficits appear to be mediated by A $\beta$ oligomers (Gong et al., 2003; Lacor et al., 2004; Lesné et al., 2006; Townsend et al., 2006; Cheng et al., 2007; Walsh and Selkoe, 2007), we wondered whether increased NEP expression can reduce $\mathrm{A} \beta$ oligomer levels in vivo and prevent oligomerrelated cognitive deficits. Eleven-fold overexpression of NEP did not reduce forebrain levels of $\mathrm{A} \beta \star 56$ or $\mathrm{A} \beta$ trimers and failed to prevent cognitive deficits and associated neuronal alterations in hAPP mice, even though it decreased overall $\mathrm{A} \beta$ levels by $>50 \%$ and effectively reduced plaque burdens.

\section{Materials and Methods}

Animals. Mice used in this study included nontransgenic (NTG) and heterozygous transgenic (TG) mice from hAPP lines J9 and J20, which express hAPP with the Swedish (K670N, M671L) and Indiana (V717F) FAD mutations (hAPP ${ }_{\mathrm{FAD}}$ ) directed by the platelet-derived growth factor $\beta$ chain promoter (Rockenstein et al., 1995; Mucke et al., 2000; Palop et al., 2003). These lines have been crossed for $>10$ generations onto the C57BL/6J background using NTG mice from The Jackson Laboratory. For some experiments, hAPP-J20 TG C57BL/6J mice were crossed with NTG DBA2J mice from The Jackson Laboratory to establish hAPP-J20 mice on the B6D2 F1 hybrid background. Mice overexpressing human NEP directed by the calcium/calmodulin-dependent kinase II $\alpha$ promoter (Leissring et al., 2003) were on the C57BL/6J background. Unless indicated otherwise, offspring from the hAPP-J $20 \times$ NEP cross were on the same background. Some experiments were performed in a mixed B6D2 background to allow for more direct comparisons with previous reports (Leissring et al., 2003; Poirier et al., 2006). After behavioral testing (see below), mice were deeply anesthetized followed by transcardial flush-perfusion with $0.9 \%$ saline and tissue isolation. All experiments were approved by the Institutional Animal Care and Use Committee of the University of California, San Francisco.

Open field. Spontaneous locomotor activity in an open field was measured in an automated Flex-Field/Open Field Photobeam Activity System (San Diego Instruments). Mice were placed in one of four identical clear plastic chambers $(41 \times 41 \times 30 \mathrm{~cm})$ for $15 \mathrm{~min}$, with two $16 \times 16$ Photobeam arrays detecting horizontal and vertical movements. Total movements (ambulations) in the outer periphery and center of the open field were reported. The apparatus was thoroughly cleaned with $70 \%$ ethanol between trials.

Elevated plus maze. The elevated plus maze consisted of two open (without walls) and two enclosed (with walls) arms elevated $63 \mathrm{~cm}$ above the ground (Hamilton-Kinder). Mice were first allowed to habituate in the testing room under dim light for $30 \mathrm{~min}$ before testing. During testing, mice were placed at the junction between the open and closed arms of the plus maze and allowed to explore for $10 \mathrm{~min}$. As a measure of general activity, total distance traveled and time spent in both the open and closed arms were calculated based on infrared Photobeam breaks. In addition, the ratios of the distance traveled in the open arms over the total distance traveled in both open and closed arms were determined as a measure of the balance between exploratory drive and anxiety. The maze was thoroughly cleaned with $70 \%$ ethanol between testing sessions.

Morris water maze. The water maze consisted of a pool $(122 \mathrm{~cm}$ diameter) filled with water $\left(18 \pm 1^{\circ} \mathrm{C}\right)$ made opaque with nontoxic white tempera paint powder and was placed in a room surrounded by distinct extramaze cues. Two identical pools were used in two different rooms, each with distinct extramaze cues. Pretraining and visible platform training were performed in one room, and hidden platform training and probe trials were performed in the other room. Mice were first given four pretraining trials in which they had to swim down a rectangular channel
$(15 \mathrm{~cm} \times 122 \mathrm{~cm})$ and mount a platform hidden $1.5 \mathrm{~cm}$ below the water surface at the end of the channel. The following day, mice were trained in the actual circular water maze. For cued training, the platform $(14 \mathrm{~cm} \times$ $14 \mathrm{~cm}$ ) was submerged $(1.5 \mathrm{~cm})$ but visibly cued with a black and white striped mast ( $15 \mathrm{~cm}$ in height). On three consecutive days, mice received two training sessions per day separated by $3-4 \mathrm{~h}$. Each session consisted of two training trials with an intertrial interval of $10 \mathrm{~min}$. For each session, the platform was moved to a new location, and the drop location was changed semirandomly between trials. Mice were then moved to the second room for hidden platform training, in which a similar platform was submerged $(1.5 \mathrm{~cm})$ and not visibly cued. On five consecutive days, mice received two training sessions separated by 3-4 h. Each session consisted of three trials (10 min between trials). The platform location remained the same throughout the hidden platform training, but the drop location was changed semirandomly between trials. Mice had $60 \mathrm{~s}$ to locate the platform during training. Mice that did not find the platform were guided to it and placed on it for $10 \mathrm{~s}$. Spatial probe trials, during which the platform was removed and mice were allowed to swim in the pool for $60 \mathrm{~s}$, were performed 16-18 h after the third day (beginning of day 4) and fifth day (beginning of day 6) of training. Escape latencies, swim paths, swim speeds, percentage time spent in each quadrant, and platform crossings were recorded with an EthoVision video tracking system (Noldus).

ELISA and Western blot analyses. The left hemibrain was snap-frozen on dry ice and stored at $-80^{\circ} \mathrm{C}$. Whole hemibrains were either used as such or dissected into two preparations: (1) hippocampal formation and (2) forebrain without hippocampal formation, thalamus, cerebellum and brainstem ("cortex-plus"). For the $\mathrm{A} \beta$ ELISA measurements of human $A \beta 1-x$ and $A \beta 1-42$, hippocampal or cortex-plus tissues were homogenized in $5 \mathrm{~m}$ guanidine buffer as described previously (Mucke et al., 2000).

For Western blot analysis of NEP levels, membrane particulate fractions were obtained as described previously (Iwata et al., 2002; Leissring et al., 2003) with slight modifications. Briefly, cortex-plus tissue was homogenized with 10 strokes of a Dounce glass homogenizer (Kontes \#18) in five volumes of homogenization buffer (50 mM Tris- $\mathrm{HCl}, \mathrm{pH}$ 7.4), containing Complete Protease Inhibitor Cocktail (Roche) and 0.7 $\mu \mathrm{g} / \mathrm{ml}$ pepstatin A. Samples were precleared by centrifuging at $2500 \times g$ for $8 \mathrm{~min}$ at $4^{\circ} \mathrm{C}$. The supernatant was then centrifuged at $100,000 \times g$ for $1 \mathrm{~h}$ at $4^{\circ} \mathrm{C}$. The pellet was resuspended in one volume of resuspension buffer (50 mu Tris-HCl, pH 7.4, 1\% Triton X-100 plus Complete Protease Inhibitor Cocktail), incubated on ice for $1 \mathrm{~h}$, and then centrifuged at $100,000 \times g$ for $1 \mathrm{~h}$ at $4^{\circ} \mathrm{C}$. The supernatant was collected and stored at $-80^{\circ} \mathrm{C}$ as the particulate membrane fraction. Protein concentrations were determined with the Bradford assay. Particulate membrane proteins $(30 \mu \mathrm{g})$ were separated on a $4-12 \%$ Bis/Tris Criterion XT gel (Bio$\mathrm{Rad})$, followed by transfer to nitrocellulose membranes $(0.2 \mu \mathrm{m}$ pore size, Bio-Rad) and Western blotting with anti-NEP (CD10, 1:500, Santa Cruz Biotechnology).

For the detection of hAPP C-terminal fragments (CTFs), cortex-plus tissues were homogenized in 9 volumes of homogenization buffer (containing, in mm: 5 HEPES, 320 sucrose, 5 benzamidine, 2 $\beta$-mercaptoethanol, 3 EGTA, $0.5 \mathrm{MgSO}_{4}, 0.5 \mathrm{Zn}_{2} \mathrm{SO}_{4}$, plus Complete Protease Inhibitor Cocktail) using a Dounce homogenizer as described above. Samples were precleared and centrifuged at $100,000 \times g$ for $1 \mathrm{~h}$ at $4^{\circ} \mathrm{C}$. The pellet was resuspended in 2.5 volumes of HEPES/sucrose buffer by pipetting and brief sonication on ice and stored at $-80^{\circ} \mathrm{C}$ as the particulate membrane fraction. Protein concentrations were determined with the micro Lowry assay. Particulate membrane proteins $(125 \mu \mathrm{g})$ were separated on a $14 \%$ Tricine gel, transferred to nitrocellulose membranes $(0.2 \mu \mathrm{m}$ pore size, Bio-Rad), and subjected to Western blotting with anti-CTF antibody (CT-15, 1:1000, kindly provided by Dr. Eddy Koo, University of California at San Diego, La Jolla, CA) as described previously (Rockenstein et al., 2005).

For detection of $\mathrm{A} \beta$ monomers and dimers, whole hemibrains were homogenized in $1.2 \mathrm{ml}$ of TBS buffer (containing, in mm: 25 Tris- $\mathrm{HCl}$, $\mathrm{pH} 7.4,140 \mathrm{NaCl}, 3 \mathrm{KCl}$, supplemented with a mixture of protein inhibitors) with a Dounce homogenizer and centrifuged at 175,000 $\times g$ for 30 min at $4^{\circ} \mathrm{C}$. Pellets were resuspended in $1.2 \mathrm{ml}$ of $1 \%$ Triton X-100/TBS, 
sonicated, homogenized, and centrifuged at $175,000 \times g$ for $30 \mathrm{~min}$ at $4^{\circ} \mathrm{C}$. Supernatants were then collected as TBST fractions, whereas pellets were resuspended in $2.4 \mathrm{ml}$ of homogenization buffer (5.0 $\mathrm{M}$ guanidine/ $\mathrm{HCl}, 50 \mathrm{~mm}$ Tris- $\mathrm{HCl}, \mathrm{pH} 8.0$ ), sonicated, homogenized, and spun at $13,000 \mathrm{rpm}$ for $10 \mathrm{~min}$ at $4^{\circ} \mathrm{C}$. Supernatants were collected as guanidine fractions. TBS and TBST fractions ( $3.5 \mathrm{mg}$ of protein each) were immunoprecipitated with $5 \mu \mathrm{l}$ of an anti-A $\beta$ antibody (6E10; Signet) overnight at $4^{\circ} \mathrm{C}$. Guanidine fractions $(100 \mu \mathrm{l}$ each) were first diluted in $3.9 \mathrm{ml}$ of DMEM (Invitrogen) and then immunoprecipitated with 6E10 overnight at $4^{\circ} \mathrm{C}$. Samples were separated on a $4-12 \%$ NuPAGE Novex Bis-Tris gel (Invitrogen), transferred to nitrocellulose membranes, and subjected to Western blotting with an anti-A $\beta$ antibody (3D6, 1:1000 dilution of 1.4 $\mathrm{mg} / \mathrm{ml}$ biotinylated stock; Elan Pharmaceuticals).

For detection of $\mathrm{A} \beta$ trimers, cortex-plus and hippocampal tissues were combined and sonicated in homogenization buffer $(50 \mathrm{~mm}$ Tris- $\mathrm{HCl}, \mathrm{pH}$ 7.5, $150 \mathrm{~mm} \mathrm{NaCl}, 5 \mathrm{~mm}$ EDTA, 0.5\% Triton X-100, 0.5\% deoxycholate, plus Complete Protease Inhibitor Cocktail) and centrifuged at 100,000 $\times$ $g$ for $1 \mathrm{~h}$ at $4^{\circ} \mathrm{C}$. The supernatant was collected and stored at $-80^{\circ} \mathrm{C}$. Samples (750 $\mu$ g of protein each) were then immunoprecipitated with an anti-A $\beta$ antibody ( $4 \mathrm{G} 8,5 \mu \mathrm{l}$, Signet) overnight at $4^{\circ} \mathrm{C}$. Samples were separated on a $10-20 \%$ Tricine Criterion XT gel (Bio-Rad), transferred to nitrocellulose membranes, and subjected to Western blotting with anti-A $\beta$ antibodies 6E10 (1:5000; Signet) or 3D6 (1:1000 dilution of 1.4 $\mathrm{mg} / \mathrm{ml}$ biotinylated stock, Elan Pharmaceuticals).

For detection of the $A \beta^{\star} 56$ oligomer, membrane fractions were isolated from a combination of cortex-plus and hippocampal tissues as described previously (Lesné et al., 2006; Cheng et al., 2007). Briefly, Protease Inhibitor Cocktail (Sigma), Phosphatase Inhibitor Cocktail 1 and 2 (Sigma), $100 \mathrm{~mm}$ phenylmethylsulfonyl fluoride in ethanol, and 20 mm phenanthrolene monohydrate in methanol were added to all homogenization buffers immediately before use. Tissues were homogenized in $\mathrm{NP}-40$ lysis buffer (containing, in mM: 50 Tris- $\mathrm{HCl}, \mathrm{pH} 7.6,0.01 \% \mathrm{NP}-$ $40,150 \mathrm{NaCl}, 2 \mathrm{EDTA}$, and $0.1 \%$ SDS plus Complete Protease Inhibitor Cocktail) and centrifuged at $3000 \mathrm{rpm}$ for $10 \mathrm{~min}$ at $4^{\circ} \mathrm{C}$. The pellet was then resuspended in TNT buffer ( $50 \mathrm{~mm}$ Tris- $\mathrm{HCl}, \mathrm{pH}$ 7.6, $150 \mathrm{~mm} \mathrm{NaCl}$, $0.1 \%$ Triton X-100) and centrifuged at $13,000 \mathrm{rpm}$ for $90 \mathrm{~min}$ at $4^{\circ} \mathrm{C}$. The remaining pellet was then resuspended in radioimmunoprecipitation assay buffer (50 mu Tris-HCl, pH 7.4, 0.5\% Triton X-100, $150 \mathrm{~mm} \mathrm{NaCl}$, $1 \mathrm{~mm}$ EDTA, 3\% SDS, $1 \%$ deoxycholate) and centrifuged at 26,000 rpm for $90 \mathrm{~min}$ at $4^{\circ} \mathrm{C}$. The supernatant was collected and stored at $-80^{\circ} \mathrm{C}$ as the membrane-bound $(\mathrm{MB})$ fraction. $\mathrm{MB}$ fractions were then precleared by incubation with protein-A and then protein-G Sepharose beads. Precleared MB fractions $(250 \mu \mathrm{g})$ were immunoprecipitated with $5 \mu \mathrm{l}$ of an anti-A $\beta$ antibody (6E10, Signet) and Protein G magnetic beads (ThermoFisher Scientific) overnight at $4^{\circ} \mathrm{C}$, separated on a $4-12 \%$ Bis/Tris Criterion XT gel (Bio-Rad), transferred to a nitrocellulose membrane and subjected to Western blotting with biotinylated anti-A $\beta$ antibody (6E10, 1:1000, Signet) and ExtrAvidin (1:5000, Sigma). A $\beta^{\star} 56$ values were normalized to hAPP levels to correct for the total amount of protein immunoprecipitated per sample. Levels of hAPP did not differ among samples within the same transgenic line of mice (data not shown).

Immunohistochemistry. The right hemibrain was drop-fixed in $4 \%$ paraformaldehyde for $48 \mathrm{~h}$ at $4^{\circ} \mathrm{C}$, rinsed in phosphate-buffered saline (PBS), and placed in a $30 \%$ sucrose solution for at least $24 \mathrm{~h}$ at $4^{\circ} \mathrm{C}$. Immunostaining was performed on sliding microtome sections $(30 \mu \mathrm{m})$ by the standard avidin-biotin/peroxidase method as described previously (Palop et al., 2003). Briefly, after quenching endogenous peroxidase activity and blocking nonspecific binding, floating sections were incubated with anti-calbindin (1:30,000; Swant), anti-Fos (Ab-5, 1:10,000; Calbiochem), or anti-A $\beta$ (3D6, 1:400 dilution of $1.97 \mathrm{mg} / \mathrm{ml}$ biotinylated stock; Elan Pharmaceuticals) antibodies at $4^{\circ} \mathrm{C}$. For the first two antibodies, sections were subsequently incubated with biotinylated goat anti-rabbit (1:200; Vector Laboratories) secondary antibodies for $1 \mathrm{~h}$ at room temperature. Diaminobenzidine was used as a chromaogen. Images were acquired on a BX-60 microscope (Olympus) and recorded with a DEI470 digital camera (Optronics). Immunoreactivities for calbindin, Fos, and $\mathrm{A} \beta$ were quantitated as described previously (Mucke et al., 2000; Palop et al., 2003; Chin et al., 2005a).

Statistical analysis. Statistical analyses were performed with StatView
5.0 (SAS Institute). Differences between means were assessed, as appropriate, by Student's $t$ test, one- or two-way ANOVA with or without repeated measures, followed by Fisher's PLSD or Tukey's post hoc tests. Correlations were assessed by simple linear regression analysis. KaplanMeier statistical methods were used to determine survival rates and hazard plots, followed by Logrank (Mantel-Cox) post hoc tests.

\section{Results}

\section{NEP overexpression reduces $A \beta$ levels and prevents early plaque deposition without altering APP processing}

hAPP TG mice from line J20 (Mucke et al., 2000) were crossed with NEP TG mice (Leissring et al., 2003), resulting in the following offspring: NTG mice, NEP or hAPP-J20 singly TG mice, and hAPP-J20/NEP doubly TG mice. Unless indicated otherwise, mice were of the C57BL/6J strain. Some experiments were performed in B6D2 mice (see Materials and Methods) to allow for more direct comparisons with previous reports (Leissring et al., 2003; Poirier et al., 2006). NEP levels in NEP mice and hAPP-J20/ NEP mice were 11-fold greater than in hAPP-J20 mice and NTG controls (Fig. 1A,B). hAPP-J20 mice and hAPP-J20/NEP mice had similar levels of hAPP C-terminal fragments (CTFs) (Fig. $1 C)$. NEP overexpression in hAPP mice reduced hippocampal and cortical $\mathrm{A} \beta$ levels by $>50 \%$ on the C57BL/6J (Fig. $1 D$ ) and B6D2 (supplemental Fig. 1, available at www.jneurosci.org as supplemental material) backgrounds. It also reduced A $\beta$ monomer levels (Fig. $1 E, F$ ) and prevented early plaque deposition in the hippocampus (Fig. 1G-J). These results are consistent with previous findings (Shirotani et al., 2001; Leissring et al., 2003; Marr et al., 2003; Iwata et al., 2004; Poirier et al., 2006) and confirm the expected biological NEP activity in our hAPP-J20/ NEP model.

\section{NEP overexpression does not prevent learning and memory deficits in hAPP mice}

To determine whether the NEP-mediated reductions in overall $\mathrm{A} \beta$ levels and in $\mathrm{A} \beta$ deposits in hAPP-J20/NEP mice were sufficient to prevent learning and memory deficits, we tested 3- to 5-month-old NTG, NEP, hAPP-J20, and hAPP-J20/NEP mice in a Morris water maze. On both the C57BL/6J and the B6D2 backgrounds, hAPP-J20 and hAPP-J20/NEP mice had similar difficulties with learning to locate the hidden platform in the spatial component of the task, compared with NTG controls (Fig. $2 A, B)$. On the C57BL/6J, but not the B6D2, background, hAPPJ20 and hAPP-J20/NEP mice also showed some deficits in the cued component of the task, although by the last day of cued training all mice performed similarly well (Fig. $2 A, B$ ). NEP mice performed as well as NTG mice in both components of the test. Comparison of swim speeds during the hidden platform training revealed no significant differences between the groups (data not shown).

To assess spatial memory formation and retention, we removed the platform for a probe trial at the beginning of the fourth day of hidden platform training. Regardless of strain background, hAPP-J20 and hAPP-J20/NEP mice spent less time searching in the target quadrant (Fig. 2C,D) and crossed over the target location less frequently (Fig. 2E,F) than NTG and NEP mice. hAPP-J20 and hAPP-J20/NEP mice did not differ significantly with respect to either outcome measure. To assess whether the different groups of mice would benefit differentially from prolonged training, we continued the hidden platform training for another $2 \mathrm{~d}$ and administered another probe trial $16-18 \mathrm{~h}$ after the last hidden platform training trial. The continued training increased target quadrant preference for both hAPP-J20 and 

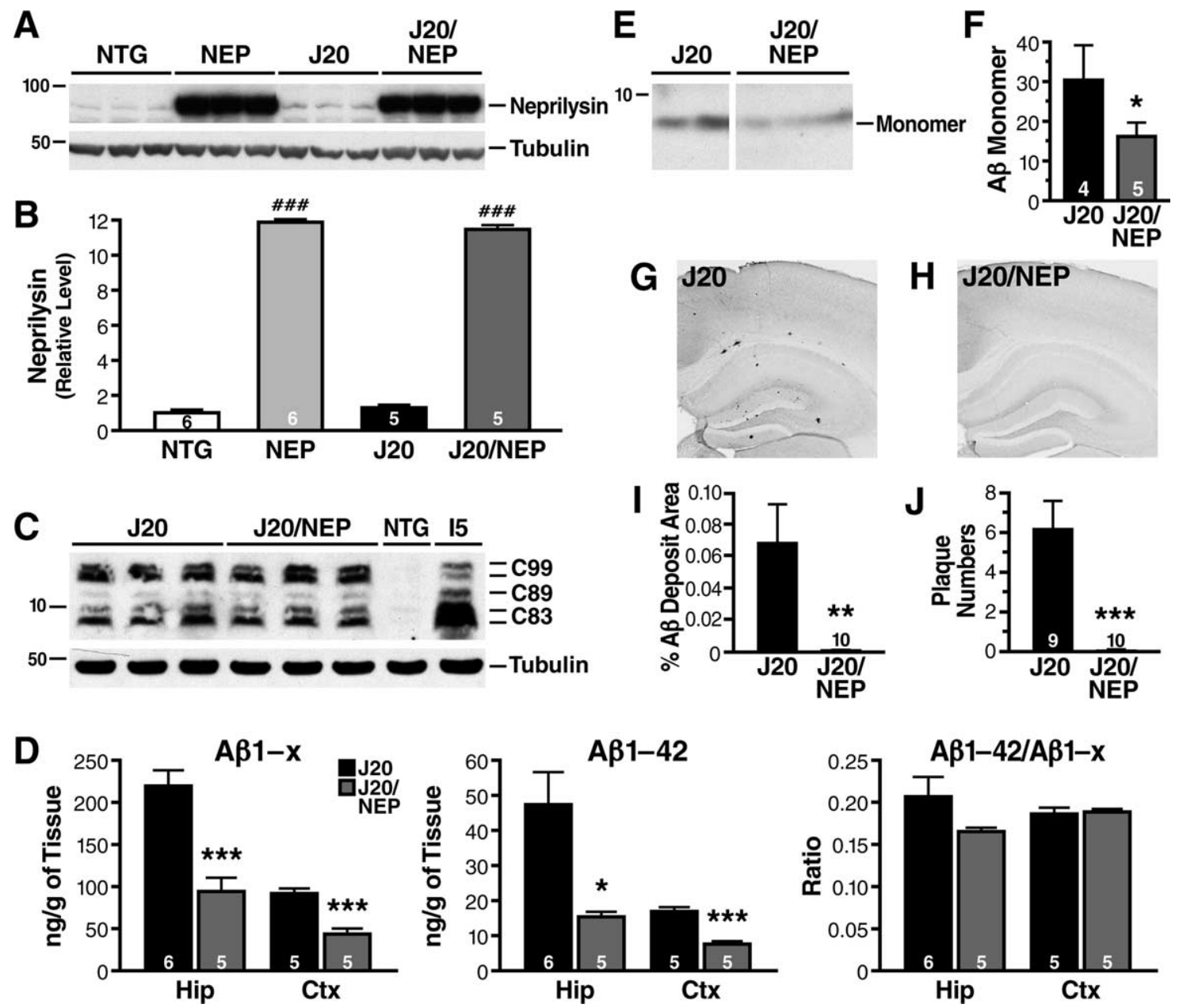

Figure 1. NEP overexpression reduces $A \beta$ levels and prevents early plaque deposition without altering levels of C-terminal APP fragments. $A, B$, Neprilysin overexpression in NEP and hAPP-J20/NEP mice was confirmed by Western blot analysis of membrane fractions isolated from cortex-plus tissues (see Materials and Methods) of 2- to 4-month-old mice. Tubulin was used as a loading control. $\boldsymbol{A}$, Representative Western blot. $\boldsymbol{B}$, Densitometric quantitation of Western blot signals revealed that NEP levels were 11-fold higher in NEP and hAPP-J20/NEP mice than in NTG controls, and that endogenous NEP levels in hAPP-J20 mice and NTG controls were similar. Numbers in bars represent numbers of mice analyzed per group. $C$, Particulate membrane fractions were isolated from cortex-plus tissues of 5- to 6-month-old hAPP-J20 and hAPP-J20/NEP mice and analyzed by Western blotting with an antibody (CT-15) against hAPP C-terminal fragments (CTFs). Tubulin was used as a loading control. Labels on the right identify bands putatively representing phosphorylated or unphosphorylated C83, C89, or C99. The rightmost lane contains a sample from a TG mouse of line 15, which expresses wild-type hAPP (Mucke et al., 2000); it illustrates that this assay was sensitive enough to detect the effect of the Swedish mutation in hAPP-J20 on (TF production. $\boldsymbol{D}, A \beta$ levels in hippocampal (Hip) and cortex-plus (Ctx) tissues of 2- to 4-month-old hAPP-J20 and hAPP-J20/NEP mice without plaques were determined by ELISA. $\boldsymbol{E}, \boldsymbol{F}$, Levels of A $\beta$ monomers in 6- to 7-month-old hAPP-J20 and hAPP-J20/NEP mice were compared by Western blot analysis of TBST fractions isolated from whole hemibrains. $\boldsymbol{E}$, Representative Western blot. $\boldsymbol{F}$, Densitometric quantitation of Western blot signals. $\mathbf{G}, \boldsymbol{H}, \mathrm{A} \beta$ deposits in hippocampal sections of 4 - to 6 -month-old hAPP-J20 and hAPP-J20/NEP mice were detected by immunostaining with the $3 \mathrm{D} 6$ antibody. $I, J$, Quantitation of percentage area occupied by A $\beta$-immunoreactive deposits $(I)$ and number of deposits $(J) .{ }^{*} p<0.05,{ }^{* *} p<0.01,{ }^{* * *} p<0.001$ versus hAPP mice (Student's $t$ test). ${ }^{\# \#} p<0.001$ versus hAPP and NTG mice (Tukey's test). Values are mean \pm SEM from mice on the C57BL/6J background.

hAPP-J20/NEP mice (Fig. 2G,H). On the C57BL/6J background, both groups still showed comparable impairments in target crossings (Fig. 2I). On the B6D2 background, only hAPP-J20 mice were impaired in this measure (Fig. $2 J$ ), although the difference between hAPP-J20 and hAPP-J20/NEP mice was not statistically significant.

Learning and memory deficits in hAPP mice correlate well with the depletion of calcium- and synaptic activity-dependent proteins in granule cells of the dentate gyrus, including calbindin- $\mathrm{D}_{28 \mathrm{~K}}$ and Fos (Palop et al., 2003; Chin et al., 2005b; Cheng et al., 2007; Roberson et al., 2007; Deipolyi et al., 2008; Meilandt et al., 2008). At 2-4 months of age, calbindin and Fos were reduced in both hAPP-J20 mice and hAPP-J20/NEP mice, compared with NTG and NEP mice, although calbindin levels were slightly higher in hAPP-J20/NEP than hAPP mice, and Fos levels showed a similar trend (Fig. 3A,C). At 5-6 months, calbindin reductions were significant only in hAPP-J20 mice (Fig. 3B), whereas Fos reductions were still prominent in both hAPP-J20 and hAPP-J20/NEP mice (Fig. 3D).

NEP overexpression does not reduce pathogenic A $\beta$ oligomers in hAPP mice

Why does a $>50 \%$ reduction of overall $A \beta$ levels fail to improve cognitive function and neuronal Fos expression in hAPP-J20/ NEP mice? To address this question, we measured $A \beta^{\star} 56$, a pathogenic $A \beta$ oligomer that correlates closely with learning and memory deficits in different lines of hAPP mice (Lesné et al., 2006; Cheng et al., 2007). A $\beta^{\star} 56$ isolated from hAPP mouse brains also elicits memory deficits when injected into the brains of NTG rats (Lesné et al., 2006). hAPP-J20 and hAPP-J20/NEP mice showed comparable levels of $A \beta^{\star} 56$ when cortex-plus and hippocampal tissues were analyzed in combination (Fig. $4 A, C$ ), and when cortex-plus was analyzed alone (data not shown), on 

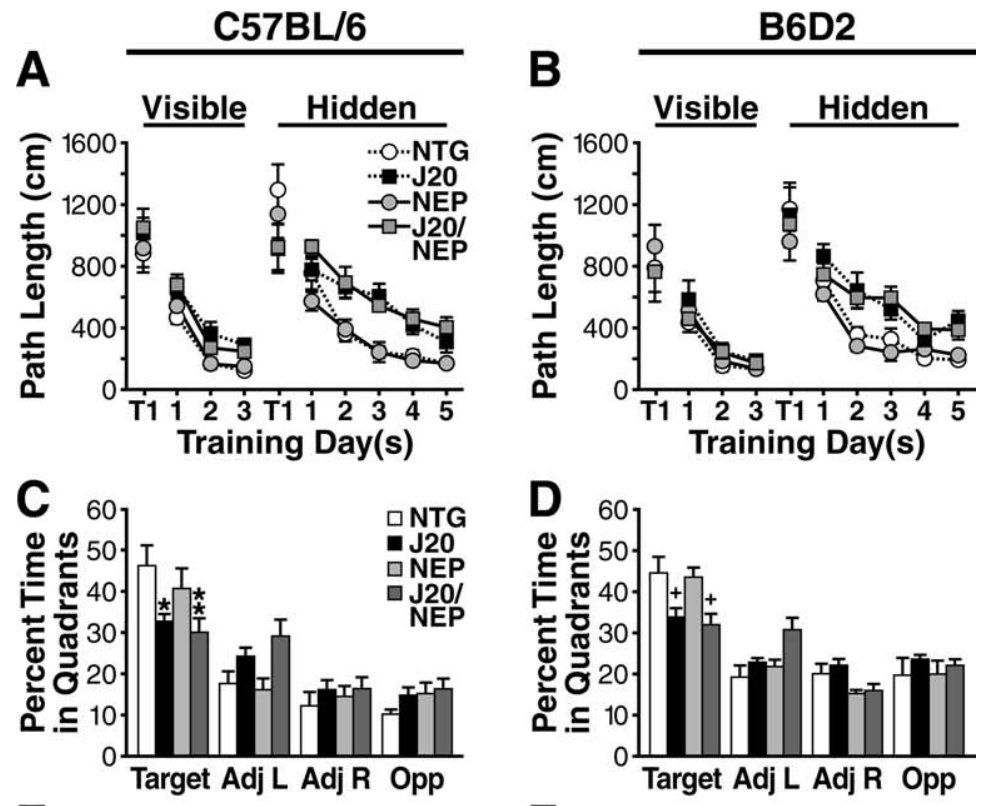

E
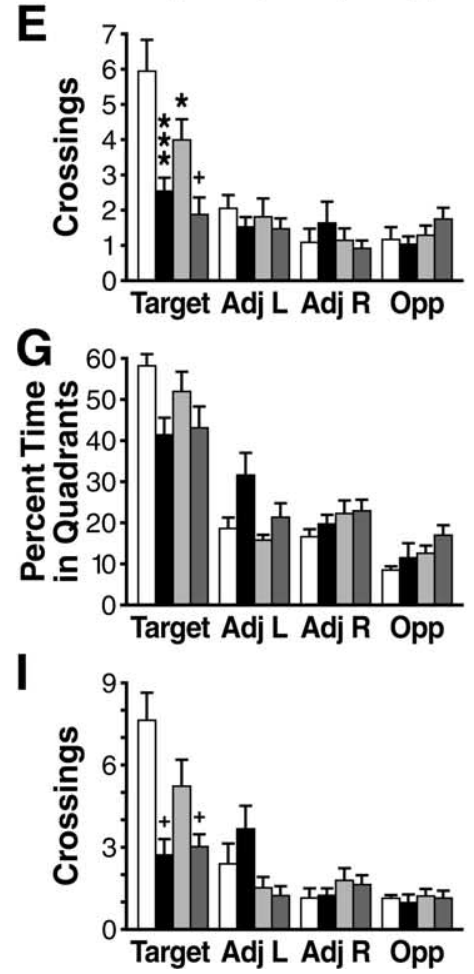

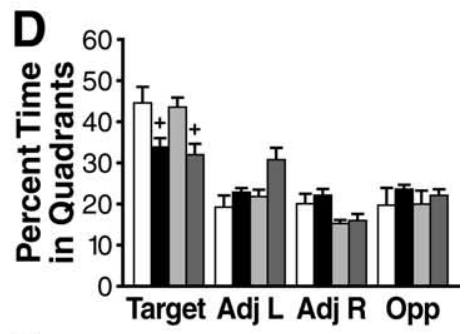

$\mathbf{F}$
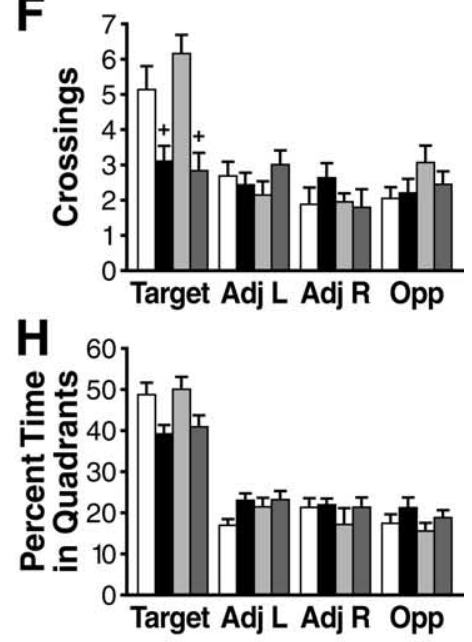

J

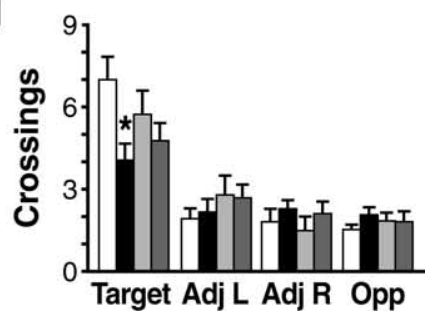

Figure 2. Overexpression of NEP in hAPP-J20 mice does not prevent learning and memory deficits in the Morris water maze. $(57 \mathrm{BL} / 6 \mathrm{~J}(\boldsymbol{A}, \boldsymbol{C}, \boldsymbol{E}, \boldsymbol{G}, \boldsymbol{I})$ and $\mathrm{B} 6 \mathrm{D} 2(\boldsymbol{B}, \boldsymbol{D}, \boldsymbol{F}, \boldsymbol{H}, \boldsymbol{J})$ mice ( $n=9-11$ mice per genotype and background) were tested at 3-5 months of age. These groups of mice had no significant differences in swim speeds during the hidden platform training (data not shown). $\boldsymbol{A}, \boldsymbol{B}$, Compared with NTG and NEP mice, hAPP-J20 and hAPP-J20/NEP mice had significant and comparable learning impairments. In both strain backgrounds, a two-way repeated measures ANOVA revealed a significant main effect of hAPP on hidden platform performance $\left(F_{(1,36)} \geq 40.4 ; p<0.001\right)$, but no NEP effect or hAPP $\times$ NEP interaction. A significant main effect of $\operatorname{hAPP}\left(F_{(1,36)}=11.0 ; p<0.01\right)$ was found in the visible platform task only on the $(57 \mathrm{BL} / 6 \mathrm{~J}$ background $(\boldsymbol{A}) . \boldsymbol{C}-\boldsymbol{J}$, Probe trials at the beginning of the fourth day of training $(\boldsymbol{C}-\boldsymbol{F})$ and $16-18 \mathrm{~h}$ after the last day of hidden platform training $(\mathbf{G}-\boldsymbol{J})$ revealed comparable impairments in hAPP-J20 and hAPP-J20/NEP mice relative to NTG and NEP mice. Target, adjacent (Adj) left (L) or right (R), and opposite (Opp) refer to quadrants $(\boldsymbol{C}, \boldsymbol{D}, \boldsymbol{G}$, and $\boldsymbol{H})$ or to the target platform and corresponding locations in the respective nontarget quadrants $(\boldsymbol{E}, \boldsymbol{F}, \boldsymbol{I}$, and $\boldsymbol{J})$. A two-way ANOVA identified a significant main effect of hAPP for the percentage of time spent in the target quadrant $\left(\boldsymbol{C}, \boldsymbol{D}, \boldsymbol{H}: \boldsymbol{F}_{(1,36)} \geq 9.7\right.$, $\left.p<0.01 ; \boldsymbol{G}: \boldsymbol{F}_{(1,36)}=6.3, p<0.05\right)$ and for the number of target crossings $\left(\boldsymbol{E}, \boldsymbol{F}, \boldsymbol{I}: \boldsymbol{F}_{(1,36)} \geq 17.7, p<0.001 ; \boldsymbol{J}: \boldsymbol{F}_{(1,36)}=\right.$ $7.0, p<0.05)$. There was no NEP effect or hAPP $\times$ NEP interaction. ${ }^{*} p<0.05,{ }^{* *} p<0.01,{ }^{* *} p<0.001$ versus NTG controls; ${ }^{+} p<0.05$ versus NTG and NEP controls (Fisher's PLSD test). Values are means \pm SEM.

either the C57BL/6J (Fig. 4A,C) or the B6D2 (data not shown) background.

Because smaller $A \beta$ assemblies, such as dimers and trimers, can also cause functional neuronal impairments and memory deficits (Townsend et al., 2006; Shankar et al., 2007; Klyubin et al., 2008; Shankar et al., 2008), we wanted to determine whether NEP overexpression reduced the levels of these species. $\mathrm{A} \beta$ trimer levels were detected in the same samples used in Figure $4 A$. Tissue lysates were immunoprecipitated with the anti-A $\beta$ antibody $4 \mathrm{G} 8$ and then examined by Western blotting with the anti-A $\beta$ antibodies 3D6 (Fig. $4 B, D)$ or $6 \mathrm{E} 10$ (data not shown). $\mathrm{A} \beta$ trimer levels were comparable in hAPP-J20 and hAPP-J20/NEP mice (Fig. 4B,D and data not shown).

$\mathrm{A} \beta \beta^{\star} 56$ and $\mathrm{A} \beta$ trimers were already detectable in hAPP-J20 mice at 1.5 months of age (data not shown), suggesting that both might contribute to the subsequent development of behavioral deficits. In contrast, $\mathrm{A} \beta$ dimers were undetectable in whole hemibrains of 3- to 8-month-old hAPPJ20 mice (Fig. 4E), making it unlikely that these assemblies contribute to the prominent cognitive deficits seen in these mice. $\mathrm{A} \beta$ dimers were detectable only in old hAPP-J20 mice (Fig. 4E), which have extensive plaque burdens (Roberson et al., 2007).

Because NEP overexpression reduced total $A \beta$ levels in hAPP mice from the high-expresser line J20 (Fig. 1D) to levels found in our lower expressing hAPP line J9 (Mucke et al., 2000), we analyzed levels of $A \beta^{\star} 56$ and $A \beta$ trimers in the latter line. Levels of $\mathrm{A} \beta^{\star} 56$ (Fig. $4 A, C$ ) and $\mathrm{A} \beta$ trimers (Fig. $4 B, D$ ) were significantly lower in hAPP-J9 mice than in hAPP-J20 and hAPP-J20/NEP mice. Thus, overall $A \beta$ levels are likely a partial, but not the sole, determinant of $A \beta^{\star} 56$ and $A \beta$ trimer levels.

\section{NEP overexpression prevents}

hyperactivity but not alterations in anxiety/exploration-related behavior in hAPP mice

In addition to deficits in learning and memory, hAPP mice and humans with $\mathrm{AD}$ have alterations in a variety of other behavioral domains (Kobayashi and Chen, 2005; Palop et al., 2006; Cheng et al., 2007; Farlow and Cummings, 2007; Palop et al., 2007; Roberson et al., 2007; Apostolova and Cummings, 2008; Deipolyi et al., 2008). Several lines of hAPP mice show greater locomotor activity in the open field test and less open arm avoidance in the elevated plus maze than NTG controls 
A

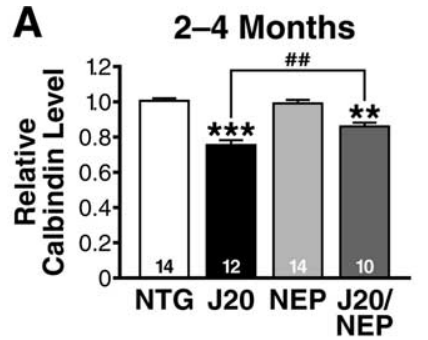

C

\section{2-4 Months}

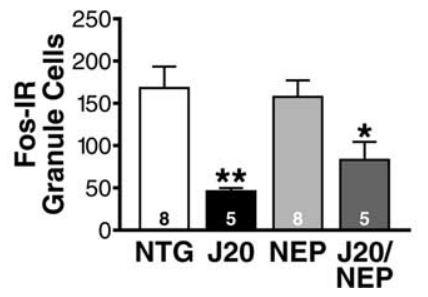

B

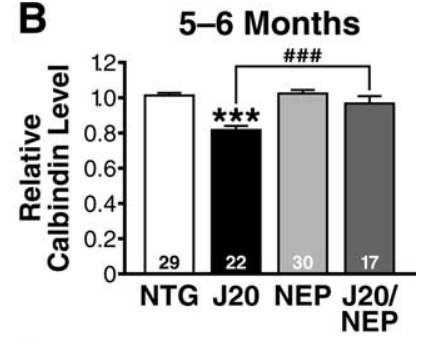

D

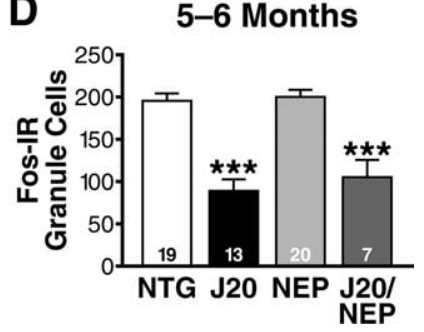

Figure 3. NEP overexpression has subtle effects on calcium- and synaptic activitydependent markers in the dentate gyrus of hAPP-J20 mice. Horizontal $(\boldsymbol{A}, \boldsymbol{B})$ or coronal $(\boldsymbol{C}, \boldsymbol{D})$ brain sections were obtained from $C 57 \mathrm{BL} / 6 \mathrm{~J}$ mice of the indicated genotypes and numbers at 2-4 $(\boldsymbol{A}, \boldsymbol{C})$ or 5-6(B, D) months of age and immunostained for calbindin $(\boldsymbol{A}, \boldsymbol{B})$ or Fos $(\boldsymbol{C}, \boldsymbol{D})$. $\boldsymbol{A}$, $\boldsymbol{B}$, For calbindin, a two-way ANOVA revealed a significant hAPP effect $\left(\boldsymbol{A}: F_{(1,46)}=44.6, p<\right.$ $\left.0.001 ; \boldsymbol{B}: \boldsymbol{F}_{(1,94)}=20.1, p<0.001\right)$ and an hAPP $\times \operatorname{NEP}$ interaction $\left(\boldsymbol{A}: \boldsymbol{F}_{(1,46)}=4.95, p<\right.$ $\left.0.05 ; \boldsymbol{B}: F_{(1,94)}=5.85, p<0.05\right)$ for both ages. $\boldsymbol{C}, \boldsymbol{D}$, For Fos, a two-way ANOVA revealed only an hAPP effect $\left(C: F_{(1,22)}=16.8, p<0.001 ; D: F_{(1,55)}=47.4, p<0.001\right)$, but no hAPP $\times$ NEP interaction. ${ }^{*} p<0.05$ versus NTG; ${ }^{* *} p<0.01,{ }^{* *} p<0.001$ versus NTG and NEP (ANOVA followed by Fisher's PLSD post hoc test). Values are means \pm SEM.

(Chin et al., 2005b; Kobayashi and Chen, 2005; Ognibene et al., 2005; Cheng et al., 2007; Roberson et al., 2007). Because these behavioral abnormalities do not correlate with $\mathrm{A} \beta \beta^{\star} 56$ levels (Cheng et al., 2007), they may be caused by other $A \beta$ assemblies, $\mathrm{A} \beta$ monomers, other hAPP metabolites, or hAPP itself. Interestingly, overexpression of NEP abolished hyperactivity in 3- to 4-month-old hAPP-J20 mice on both the C57BL/6J and the B6D2 backgrounds (Fig. $5 A, B$ ), suggesting that this behavioral abnormality may depend on $A \beta$ monomers, which were lower in hAPP-J20/NEP than hAPP-J20 mice (Fig. $1 E, F$ ), but not on levels of $\mathrm{A} \beta^{\star} 56$ or $\mathrm{A} \beta$ trimers, which were comparable in both groups (Fig. $4 A-D$ ).

The elevated plus maze is often used to examine the balance between anxiety and exploratory drive (Belzung and Griebel, 2001). hAPP mice display an anxiolytic or disinhibition-like phenotype in this paradigm, avoiding the open arms less than NTG controls (Chin et al., 2005b; Kobayashi and Chen, 2005; Cheng et al., 2007; Roberson et al., 2007). hAPP-J20 and hAPP-J20/NEP mice showed comparable abnormalities in this paradigm, with both groups traveling a greater distance in the open arms than NTG and NEP mice (Fig. 5C,D).

\section{Effect of NEP overexpression on premature mortality in} hAPP mice

NEP overexpression has been reported to diminish premature mortality during the first 6 months of life in hAPP-J20 mice on the B6D2 background (Leissring et al., 2003). To confirm and extend these results, we compared the survival of NTG, hAPPJ20, NEP, and hAPP-J20/NEP mice on the B6D2 and the C57BL/6J backgrounds between postnatal day 14 and 17 months. Surprisingly, overexpression of NEP in hAPP-J20/NEP mice did not improve premature mortality on the B2D6 background and actually worsened it on the C57BL/6 background (Fig. 6), com-

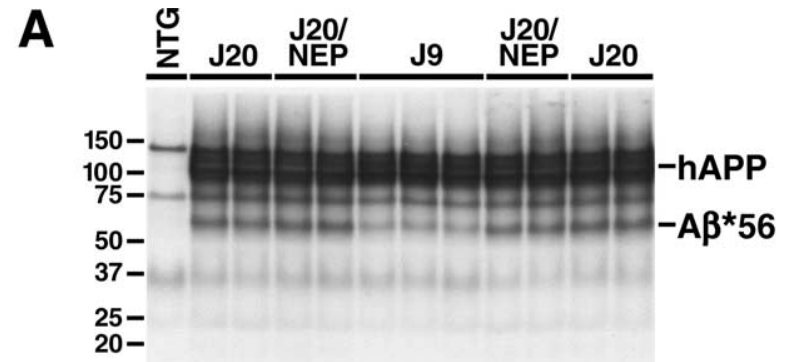

\section{Shorter
Exposure}
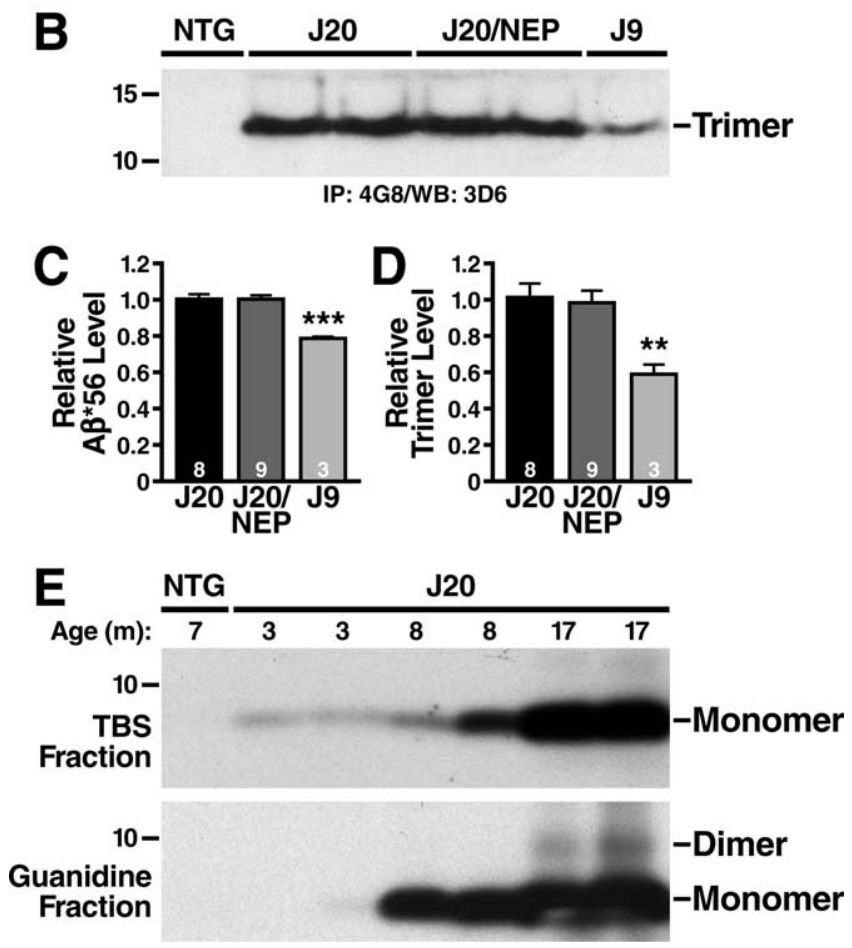

Figure 4. Overexpression of NEP does not reduce levels of $A \beta^{*} 56$ or $A \beta$ trimers. Different $A \beta$ assemblies were measured in 5- to 6-month-old hAPP ${ }_{F A D} T G$ C57BL/6J mice from line J20 and from the lower expresser line J9. $A$, Representative Western blot of membrane-enriched fractions from combined hippocampal and cortex-plus lysates probed with the anti-A $\beta$ antibody $6 \mathrm{E} 10$, which recognizes $A \beta^{*} 56$ and hAPP, as indicated on right. $\boldsymbol{B}, A \beta$ trimers in soluble fractions of combined hippocampal and cortex-plus lysates were immunoprecipitated with the anti-A $\beta$ antibody $4 G 8$ and detected by Western blotting with the anti-A $\beta$ antibody 3D6. C, D, Relative levels of $A \beta^{*} 56(\boldsymbol{C})$ and $A \beta$ trimers $(\boldsymbol{D})$ were determined by densitometric analysis of Western blot signals. $\boldsymbol{E}$, Representative Western blot of TBS and guanidine fractions isolated from hemibrains of 3- to 17-month-old hAPP-J20 mice. A $\beta$ monomers and dimers were immunoprecipitated with the $6 \mathrm{E} 10$ antibody and detected by Western blotting with the 3D6 antibody. Note that dimers were detected only in 17-month-old mice. Similar results were obtained with TBST fractions (data not shown). ${ }^{* *} p<0.01,{ }^{* * *} p<0.001$ versus hAPP-J20 and hAPPJ20/NEP mice (Tukey's test). Values are means \pm SEM.

pared with hAPP-J20 mice. Premature mortality of hAPP-J20/ NEP mice was greater in the C57BL/6J background than in the B2D6 background, whereas premature mortality of hAPP-J20 mice was not affected by background (Fig. 6). In the absence of hAPP/A $\beta$, overexpression of NEP did not affect survival in either background (Fig. 6).

To determine whether the increased mortality of hAPP-J20/ NEP mice on the C57BL/6J background was caused by an interaction between NEP and high levels of either hAPP or A $\beta$, we crossed NEP mice with TG mice expressing wild-type hAPP at 

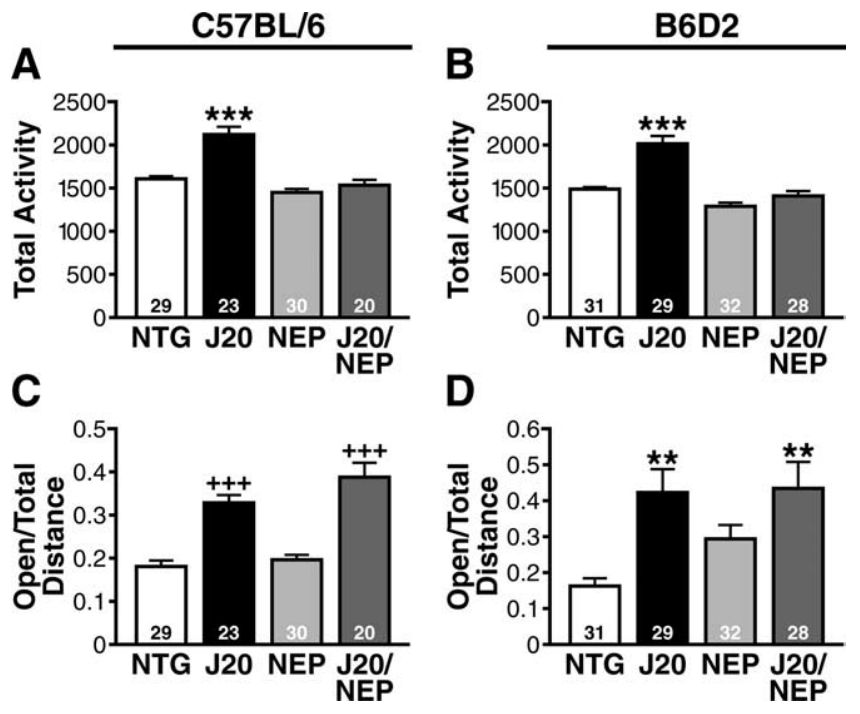

Figure 5. $A-D$, Overexpression of NEP prevents hyperactivity but does not alter elevated plus maze abnormalities in hAPP-J20 mice. Total activity in the periphery of an open field $(\boldsymbol{A}, \boldsymbol{B})$ and the proportional distance traveled in the open arms of an elevated plus maze $(\boldsymbol{C}, \boldsymbol{D})$ were compared among $(57 \mathrm{BL} / 6)(\boldsymbol{A}, \boldsymbol{C})$ and B6D2 $(\boldsymbol{B}, \boldsymbol{D})$ mice of the indicated genotypes at 3-4 months of age. A two-way ANOVA revealed an hAPP effect $\left(\boldsymbol{A}: \boldsymbol{F}_{(1,98)}=13.0, p<0.001 ; \boldsymbol{B}\right.$ : $\left.F_{(1,116)}=12.9, p<0.001 ; C: F_{(1,98)}=46.5, p<0.001 ; D: F_{(1,116)}=10.8, p<0.01\right)$ and an $\mathrm{hAPP} \times \operatorname{NEP}$ interaction $\left(\boldsymbol{A}: \boldsymbol{F}_{(1,98)}=8.3, p<0.01 ; \boldsymbol{B}: \boldsymbol{F}_{(1,116)}=5.22, p<0.05\right) .{ }^{* *} p<0.01$ versus NTG mice, ${ }^{* * *} p<0.001$ versus all other groups; ${ }^{+++} p<0.001$ versus NTG and NEP mice (Fisher's PLSD test). Values are means \pm SEM.

high levels (line I5) or with TG mice expressing FAD-mutant hAPP at lower levels (line J9) (Mucke et al., 2000; Palop et al., 2003). Average levels of hAPP expression are approximately comparable in TG mice from lines I5 and J20, whereas A $\beta$ levels are much lower in I5 than J20 mice (Mucke et al., 2000; Meilandt et al., 2008). Average levels of hAPP and $A \beta$ in J9 mice are approximately one-half of those in 20 mice (Mucke et al., 2000). Overexpression of NEP had no effect on survival in hAPP-I5 mice and hAPP-J9 mice (supplemental Fig. 2, available at www.jneurosci.org as supplemental material).

\section{Discussion}

This study demonstrates that 11-fold NEP overexpression does not reduce pathogenic $A \beta$ oligomers or improve memory deficits and abnormal anxiety/exploration-related behaviors in hAPPJ20 mice. However, it effectively reduced overall $A \beta$ levels, $A \beta$ monomers, and plaque burdens. Thus, overall $A \beta$ and monomer levels and plaque loads are unreliable indicators of $\mathrm{AD}$-related functional impairments, particularly regarding therapies that fail to lower $\mathrm{A} \beta$ oligomer levels.

NEP's inability to reduce $A \beta$ trimers or cognitive deficits in vivo agrees with its inability to degrade such $\mathrm{A} \beta$ assemblies in vitro (Leissring et al., 2003) and with deleterious effects of $A \beta$ trimers on neuronal function (Townsend et al., 2006). The putative dodecamer $\mathrm{A} \beta^{\star} 56$ that correlates with memory deficits in hAPP mice (Lesné et al., 2006; Cheng et al., 2007) is also likely resistant to NEP because its levels were similar in hAPP-J20 and hAPP-J20/NEP mice. Because A $\beta$ dimers appeared only months after functional deficits, they are unlikely to contribute to behavioral alterations in hAPP-J20 mice. In contrast, $A \beta^{\star} 56$ and $A \beta$ trimers occurred before these alterations emerged and, thus, are a likelier cause of neuronal dysfunction in this model.

In contrast to our study, others reported that NEP overexpression prevents learning and memory deficits in hAPP mice
(Poirier et al., 2006). Different levels, times, and patterns of transgene expression may account for the discrepancy. Brain NEP activity was $\sim 30$-fold higher than controls in their NEP TG line (Poirier et al., 2006) and $\sim 8$-fold higher in the line we used (Leissring et al., 2003). The CaMKII promoter used in our line directs expression late in postnatal development (P3-P15) and predominantly within forebrain excitatory neurons (Mayford et al., 1997; Solà et al., 1999). The PrP promoter used in their line directs expression at E13.5 and in additional neuronal populations, including inhibitory interneurons (Manson et al., 1992; Weber et al., 2001; Bailly et al., 2004). Because Poirier and colleagues did not measure $A \beta$ oligomer levels, it is unclear whether the behavioral benefits they reported were associated with a reduction in these moieties.

Learning and memory deficits in hAPP mice correlate with the depletion of calcium- and synaptic activity-dependent proteins in granule cells of the dentate gyrus, likely reflecting compensatory responses to $\mathrm{A} \beta$-induced alterations in neuronal activity (Palop et al., 2003; Chin et al., 2005b; Cheng et al., 2007; Palop et al., 2007; Roberson et al., 2007; Deipolyi et al., 2008; Meilandt et al., 2008). NEP overexpression did not improve $A \beta$-dependent reductions in neuronal Fos expression. However, neuronal calbindin levels subtly improved in hAPP-J20/NEP mice over hAPPJ20 mice, which may reflect different sensitivities of these biomarkers.

NEP overexpression prevented hyperactivity in hAPP-J20 mice. Because A $\beta$ oligomer levels in hAPP-J20 and hAPP-J20/ NEP mice were comparable, hyperactivity is more likely caused by monomeric $A \beta$ than $A \beta^{\star} 56$ or $A \beta$ trimers. It also does not correlate with $\mathrm{A} \beta^{\star} 56$ levels in hAPP mice (Cheng et al., 2007). Although another $A \beta$ assembly might produce hyperactivity, we doubt that plaques do, because hyperactivity occurs before plaques form.

Several hAPP lines, including hAPP-J20, show decreased open arm avoidance in the elevated plus maze (Chin et al., 2005b; Kobayashi and Chen, 2005; Cheng et al., 2007; Roberson et al., 2007). NEP overexpression did not prevent this abnormality in hAPP-J20 mice, suggesting it may be caused by $\mathrm{A} \beta \beta^{\star} 56$ or $\mathrm{A} \beta$ trimers rather than monomers or plaques. However, decreased open arm avoidance did not correlate with forebrain $\mathrm{A} \beta^{\star} 56$ levels (Cheng et al., 2007). Because quantifying $A \beta^{\star} 56$ levels in small samples is difficult, we cannot exclude effects of $A \beta^{\star} 56$ or $A \beta$ trimers on specific brain regions, such as the amygdala; other $A \beta$ assemblies and hAPP metabolites may contribute also.

Comparing hAPP-J20/NEP mice with hAPP-J20 and hAPP-J9 mice may yield insights into formation and accumulation of pathogenic $\mathrm{A} \beta$ oligomers in the brain. Overall $\mathrm{A} \beta$ levels in hAPPJ20 mice were twice those in hAPP-J9 mice, and A $\beta^{\star} 56$ levels were significantly higher in hAPP-J20 than hAPP-J9 mice, suggesting that overall $\mathrm{A} \beta$ levels do affect accumulation of pathogenic oligomers. Overexpression of NEP in young hAPP-J20/ NEP mice decreased $A \beta$ monomers and overall $A \beta$ levels by $>50 \%$, to levels below those found in hAPP-J9 mice. This A $\beta$ reduction decreased $A \beta$ deposition, but had no effect on oligomers. Indeed, $A \beta^{\star} 56$ and $A \beta$ trimer levels were comparable in hAPP-J20 and hAPP-J20/NEP mice and lower in hAPP-J9 mice. Thus, formation of $A \beta$ oligomers and formation/deposition of $\mathrm{A} \beta$ fibrils may follow distinct pathways in vivo.

NEP's extracellular/intraluminal active site degrades $\mathrm{A} \beta 1-42$ ineffectively within intracellular compartments in which $\mathrm{A} \beta$ trimers may form (Walsh et al., 2000; Hama et al., 2004; Iwata et al., 2004). Because NEP cannot degrade $A \beta$ trimers in cell-free conditions (Leissring et al., 2003), increased NEP activity is unlikely 
to affect these assemblies after they form. If NEP-resistant trimers represent building blocks of $\mathrm{A} \beta{ }^{\star} 56$, which presumably forms extracellularly (Lesné et al., 2006), NEP would not be expected to affect the formation or stability of $A \beta^{\star} 56$.

Pharmacological inhibition of neprilysin increased $A \beta$ dimers and trimers in neprilysin-transfected HEK293 cells (Kanemitsu et al., 2003), and genetically reducing NEP levels increased $A \beta$ dimers in the brain of plaque-bearing hAPP mice (Huang et al., 2006; Farris et al., 2007). NEP may prevent accumulation of these assemblies by degrading monomers as it cannot degrade dimers or trimers in cellfree conditions (Leissring et al., 2003). Many dimers may form extracellularly, where NEP effectively degrades A $\beta 1-42$ monomers (Hama et al., 2004). NEP reduction in vivo also increased trimer levels, although the effect was much more subtle and variable than with dimers (Huang et al., 2006). NEP's $A \beta$ degrading capacity might be improved in vivo through cooperation with other $A \beta$ degrading enzymes, such as cathepsin B (Mueller-Steiner et al., 2006).

Why does NEP overexpression reduce formation of plaques but not $\mathrm{A} \beta \beta^{\star} 56$ and trimers? Because $\mathrm{A} \beta$ dimer accumulation closely parallels the appearance of SDS-insoluble fibrillar A $\beta$ (Kawarabayashi et al., 2004), formation of dimers and plaques may be causally related. Dimers may represent a critical nucleation step toward fibrillization (Congdon et al., 2008), whereas trimers may be critical for the formation of $A \beta^{\star} 56$ and other higher-order nonfibrillar assemblies. Assuming NEP reduces $A \beta$ dimers more than trimers, this differential assembly hypothesis could explain why NEP overexpression reduces plaques but not $\mathrm{A} \beta \star 56$. If $\mathrm{A} \beta$ oligomer formation required fewer $\mathrm{A} \beta$ monomers than plaque formation, overall A $\beta$ levels in hAPP-J20/NEP mice may not be low enough to affect oligomer formation. We consider this unlikely, though, because overall $A \beta$ levels were slightly lower in hAPP-J20/NEP than hAPP-J9 mice, whereas A $\beta$ oligomer levels were higher in hAPP-J20/NEP mice.

Interestingly, NEP ablation in line APP23 worsened behavioral abnormalities and was associated with subtle increases in trimers and tetramers (Huang et al., 2006). Therefore, NEP may have a small effect on $\mathrm{A} \beta$ trimers and higher-order oligomers. NEP ablation may increase $A \beta$ oligomer levels above a pathogenic threshold in APP23 mice, bringing out functional deficits. $\mathrm{A} \beta$ oligomer levels in hAPP-J20 mice may be so high that NEP overexpression cannot reduce them below this threshold.

Because NEP overexpression had no effect on hAPP levels, hAPP-J20 and hAPP-J20/NEP mice have higher hAPP levels than hAPP-J9 mice. Might another hAPP metabolite regulate $\mathrm{A} \beta$ oligomer levels? Candidates include the secreted KPIcontaining ectodomain of hAPP, which functions as a protease inhibitor (Van Nostrand et al., 1989) and could inhibit a putative protease that clears $\mathrm{A} \beta$ oligomers. This effect might cause higher $A \beta$ oligomer levels in hAPP-J20/NEP than hAPP-J9 mice. Finally, hAPP's intracellular domain (Marks and Berg, 2003; Tagami et al., 2008) may regulate factors involved in forming or clearing $A \beta$ oligomers. These possibilities are not mutually exclusive.
NEP overexpression had a surprising effect on premature mortality in hAPP-J20 mice. Premature mortality occurs in diverse hAPP lines with high A $\beta$ levels (Hsiao et al., 1995; Moechars et al., 1999b; Moechars et al., 1999a; McLaurin et al., 2006; Cheng et al., 2007; Roberson et al., 2007). hAPP-J20/ NEP mice on a mixed B6D2 background lived longer than hAPP-J20 mice (Leissring et al., 2003). In our study, NEP overexpression did not decrease premature mortality in hAPP-J20/NEP mice on a B6D2 background and increased it on a C57BL/6J background. Differences in husbandry conditions and procedures to detect early deaths may account for the difference. Our results agree with a study demonstrating that NEP overexpression reduces $A \beta$ accumulation but does not prevent neurodegeneration or premature mortality in $\mathrm{A} \beta$ transgenic flies (Iijima et al., 2008).

Because NEP overexpression reduced overall $\mathrm{A} \beta$ levels, but not $A \beta$ oligomers or premature mortality in hAPP mice, premature mortality may be related more closely to $A \beta$ oligomers than to $\mathrm{A} \beta$ monomers. Manipulations that increase or decrease $\mathrm{A} \beta$ oligomer-related memory deficits also increase or decrease premature mortality in hAPP mice, respectively (McLaurin et al., 2006; Cheng et al., 2007; Roberson et al., 2007). What increased premature mortality in hAPP-J20/NEP mice on the C57BL/6J background is unknown. Premature mortality in hAPP mice is not understood in general, although $\mathrm{A} \beta$-induced epileptic activity may be involved (Moechars et al., 1999a; Lhatoo and Sander, 2005; Palop et al., 2007; Roberson et al., 2007). A range of alternative NEP substrates regulates neuronal activity (Sakurada et al., 1990; Turner et al., 2001); alterations in their levels might sensitize $\mathrm{C} 57 \mathrm{BL} / 6 \mathrm{~J}$ mice to pathogenic $\mathrm{A} \beta$ effects.

Our study suggests that increasing NEP activity in the context of high $\mathrm{A} \beta$ oligomer levels may have limited therapeutic benefit and could be associated with untoward side effects. Identifying and harnessing alternative $\mathrm{A} \beta$-degrading enzymes that more effectively destroy pathogenic oligomers are more promising objectives. 


\section{References}

Apostolova LG, Cummings JL (2008) Neuropsychiatric manifestations in mild cognitive impairment: a systematic review of the literature. Dement Geriatr Cogn Disord 25:115-126.

Bailly Y, Haeberlé AM, Blanquet-Grossard F, Chasserot-Golaz S, Grant N, Schulze T, Bombarde G, Grassi J, Cesbron JY, Lemaire-Vieille C (2004) Prion protein $\left(\mathrm{PrP}^{\mathrm{c}}\right)$ immunocytochemistry and expression of the green fluorescent protein reporter gene under control of the bovine PrP gene promoter in the mouse brain. J Comp Neurol 473:244-269.

Belzung C, Griebel G (2001) Measuring normal and pathological anxietylike behaviour in mice: a review. Behav Brain Res 125:141-149.

Blennow K, de Leon MJ, Zetterberg H (2006) Alzheimer's disease. Lancet 368:387-403.

Caccamo A, Oddo S, Sugarman MC, Akbari Y, LaFerla FM (2005) Age- and region-dependent alterations in Abeta-degrading enzymes: implications for Abeta-induced disorders. Neurobiol Aging 26:645-654.

Cheng IH, Scearce-Levie K, Legleiter J, Palop JJ, Gerstein H, Bien-Ly N, Puoliväli J, Lesné S, Ashe KH, Muchowski PJ, Mucke L (2007) Accelerating amyloid- $\beta$ fibrillization reduces oligomer levels and functional deficits in Alzheimer disease mouse models. J Biol Chem 282:23818-23828.

Chesneau V, Vekrellis K, Rosner MR, Selkoe DJ (2000) Purified recombinant insulin-degrading enzyme degrades amyloid $\beta$-protein but does not promote its oligomerization. Biochem J 351:509-516.

Chin J, Palop J, Puoliväli J, Massaro C, Bien-Ly N, Gerstein H, Scearce-Levie K, Mucke L (2005a) Increasing Fyn kinase activity in APP transgenic mice impairs Arc expression induced by novel environment exposure. Soc Neurosci Abstr 31:324.325.

Chin J, Palop JJ, Puoliväli J, Massaro C, Bien-Ly N, Gerstein H, Scearce-Levie K, Masliah E, Mucke L (2005b) Fyn kinase induces synaptic and cognitive impairments in a transgenic mouse model of Alzheimer's disease. J Neurosci 25:9694-9703.

Choi DS, Wang D, Yu GQ, Zhu G, Kharazia VN, Paredes JP, Chang WS, Deitchman JK, Mucke L, Messing RO (2006) PKC $\varepsilon$ increases endothelin converting enzyme activity and reduces amyloid plaque pathology in transgenic mice. Proc Natl Acad Sci U S A 103:8215-8220.

Congdon EE, Kim S, Bonchak J, Songrug T, Matzavinos A, Kuret J (2008) Nucleation-dependent tau filament formation: The importance of dimerization and an estimation of elementary rate constants. J Biol Chem 283:13806-13816.

Deipolyi AR, Fang S, Palop JJ, Yu G-Q, Wang X, Mucke L (2008) Altered navigational strategy use and visuospatial deficits in hAPP transgenic mice. Neurobiol Aging 29:253-266.

Farlow MR, Cummings JL (2007) Effective pharmacologic management of Alzheimer's disease. Am J Med 120:388-397.

Farris W, Schütz SG, Cirrito JR, Shankar GM, Sun X, George A, Leissring MA, Walsh DM, Qiu WQ, Holtzman DM, Selkoe DJ (2007) Loss of neprilysin function promotes amyloid plaque formation and causes cerebral amyloid angiopathy. Am J Pathol 171:241-251.

Ferri CP, Prince M, Brayne C, Brodaty H, Fratiglioni L, Ganguli M, Hall K, Hasegawa K, Hendrie H, Huang Y, Jorm A, Mathers C, Menezes PR, Rimmer E, Scazufca M (2005) Global prevalence of dementia: a Delphi consensus study. Lancet 366:2112-2117.

Gan L, Mucke L (2008) Paths of convergence: sirtuins in aging and neurodegeneration. Neuron 58:10-14.

Gong Y, Chang L, Viola KL, Lacor PN, Lambert MP, Finch CE, Krafft GA, Klein WL (2003) Alzheimer's disease-affected brain: presence of oligomeric A $\beta$ ligands (ADDLs) suggests a molecular basis for reversible memory loss. Proc Natl Acad Sci U S A 100:10417-10422.

Hama E, Shirotani K, Iwata N, Saido TC (2004) Effects of neprilysin chimeric proteins targeted to subcellular compartments on amyloid $\beta$ peptide clearance in primary neurons. J Biol Chem 279:30259-30264.

Hellström-Lindahl E, Ravid R, Nordberg A (2008) Age-dependent decline of neprilysin in Alzheimer's disease and normal brain: Inverse correlation with A $\beta$ levels. Neurobiol Aging 29:210-221.

Hsiao KK, Borchelt DR, Olson K, Johannsdottir R, Kitt C, Yunis W, Xu S, Eckman C, Younkin S, Price D, Iadecola C, Clark HB, Carlson G (1995) Age-related CNS disorder and early death in transgenic FVB/N mice overexpressing Alzheimer amyloid precursor proteins. Neuron 15:1203-1218.

Huang SM, Mouri A, Kokubo H, Nakajima R, Suemoto T, Higuchi M, Staufenbiel M, Noda Y, Yamaguchi H, Nabeshima T, Saido TC, Iwata N (2006) Neprilysin-sensitive synapse-associated amyloid-beta peptide oligomers impair neuronal plasticity and cognitive function. J Biol Chem 281:17941-17951.

Iijima K, Chiang HC, Hearn SA, Hakker I, Gatt A, Shenton C, Granger L, Leung A, Iijima-Ando K, Zhong Y (2008) A $\beta 42$ mutants with different aggregation profiles induce distinct pathologies in Drosophila. PLoS One 3:e1703.

Iwata N, Tsubuki S, Takaki Y, Shirotani K, Lu B, Gerard NP, Gerard C, Hama E, Lee HJ, Saido TC (2001) Metabolic regulation of brain A $\beta$ by neprilysin. Science 292:1550-1552.

Iwata N, Takaki Y, Fukami S, Tsubuki S, Saido TC (2002) Region-specific reduction of A beta-degrading endopeptidase, neprilysin, in mouse hippocampus upon aging. J Neurosci Res 70:493-500.

Iwata N, Mizukami H, Shirotani K, Takaki Y, Muramatsu S, Lu B, Gerard NP, Gerard C, Ozawa K, Saido TC (2004) Presynaptic localization of neprilysin contributes to efficient clearance of amyloid-beta peptide in mouse brain. J Neurosci 24:991-998.

Iwata N, Higuchi M, Saido TC (2005) Metabolism of amyloid- $\beta$ peptide and Alzheimer's disease. Pharmacol Ther 108:129-148.

Kanemitsu H, Tomiyama T, Mori H (2003) Human neprilysin is capable of degrading amyloid $\beta$ peptide not only in the monomeric form but also the pathological oligomeric form. Neurosci Lett 350:113-116.

Kawarabayashi T, Shoji M, Younkin LH, Wen-Lang L, Dickson DW, Murakami T, Matsubara E, Abe K, Ashe KH, Younkin SG (2004) Dimeric amyloid beta protein rapidly accumulates in lipid rafts followed by apolipoprotein E and phosphorylated tau accumulation in the Tg2576 mouse model of Alzheimer's disease. J Neurosci 24:3801-3809.

Klyubin I, Betts V, Welzel AT, Blennow K, Zetterberg H, Wallin A, Lemere CA, Cullen WK, Peng Y, Wisniewski T, Selkoe DJ, Anwyl R, Walsh DM, Rowan MJ (2008) Amyloid $\beta$ protein dimer-containing human CSF disrupts synaptic plasticity: prevention by systemic passive immunization. J Neurosci 28:4231-4237.

Kobayashi DT, Chen KS (2005) Behavioral phenotypes of amyloid-based genetically modified mouse models of Alzheimer's disease. Genes Brain Behav 4:173-196.

Lacor PN, Buniel MC, Chang L, Fernandez SJ, Gong Y, Viola KL, Lambert MP, Velasco PT, Bigio EH, Finch CE, Krafft GA, Klein WL (2004) Synaptic targeting by Alzheimer's-related amyloid $\beta$ oligomers. J Neurosci 24:10191-10200.

Leissring MA, Farris W, Chang AY, Walsh DM, Wu X, Sun X, Frosch MP, Selkoe DJ (2003) Enhanced proteolysis of $\beta$-amyloid in APP transgenic mice prevents plaque formation, secondary pathology, and premature death. Neuron 40:1087-1093.

Lesné S, Koh MT, Kotilinek L, Kayed R, Glabe CG, Yang A, Gallagher M, Ashe $\mathrm{KH}$ (2006) A specific amyloid- $\beta$ protein assembly in the brain impairs memory. Nature 440:352-357.

Lhatoo SD, Sander JW (2005) Cause-specific mortality in epilepsy. Epilepsia 46 (Suppl 11):36-39.

Manson J, West JD, Thomson V, McBride P, Kaufman MH, Hope J (1992) The prion protein gene: a role in mouse embryogenesis? Development 115:117-122.

Marks N, Berg MJ (2003) APP processing enzymes (secretases) as therapeutic targets: insights from the use of transgenics (Tgs) and transfected cells. Neurochem Res 28:1049-1062.

Marr RA, Rockenstein E, Mukherjee A, Kindy MS, Hersh LB, Gage FH, Verma IM, Masliah E (2003) Neprilysin gene transfer reduces human amyloid pathology in transgenic mice. J Neurosci 23:1992-1996.

Mayford M, Mansuy IM, Muller RU, Kandel ER (1997) Memory and behavior: a second generation of genetically modified mice. Curr Biol 7:R580-R589.

McLaurin J, Kierstead ME, Brown ME, Hawkes CA, Lambermon MH, Phinney AL, Darabie AA, Cousins JE, French JE, Lan MF, Chen F, Wong SS, Mount HT, Fraser PE, Westaway D, St George-Hyslop P (2006) Cyclohexanehexol inhibitors of Abeta aggregation prevent and reverse Alzheimer phenotype in a mouse model. Nat Med 12:801-808.

Meilandt WJ, Yu GQ, Chin J, Roberson ED, Palop JJ, Wu T, Scearce-Levie K, Mucke L (2008) Enkephalin elevations contribute to neuronal and behavioral impairments in a transgenic mouse model of Alzheimer's disease. J Neurosci 28:5007-5017.

Moechars D, Lorent K, Van Leuven F (1999a) Premature death in transgenic mice that overexpress a mutant amyloid precursor protein is preceded by severe neurodegeneration and apoptosis. Neuroscience 91:819-830. 
Moechars D, Dewachter I, Lorent K, Reversé D, Baekelandt V, Naidu A, Tesseur I, Spittaels K, Van Den Haute CV, Checler F, Godaux E, Cordell B, Van Leuven F (1999b) Early phenotypic changes in transgenic mice that overexpress different mutants of amyloid precursor protein in brain. J Biol Chem 274:6483-6492.

Mouri A, Zou LB, Iwata N, Saido TC, Wang D, Wang MW, Noda Y, Nabeshima T (2006) Inhibition of neprilysin by thiorphan (i.c.v.) causes an accumulation of amyloid $\beta$ and impairment of learning and memory. Behav Brain Res 168:83-91.

Mucke L, Masliah E, Yu GQ, Mallory M, Rockenstein EM, Tatsuno G, Hu K, Kholodenko D, Johnson-Wood K, McConlogue L (2000) High-level neuronal expression of $\mathrm{A} \beta_{1-42}$ in wild-type human amyloid protein precursor transgenic mice: synaptotoxicity without plaque formation. J Neurosci 20:4050-4058.

Mueller-Steiner S, Zhou Y, Arai H, Roberson ED, Sun B, Chen J, Wang X, Yu G, Esposito L, Mucke L, Gan L (2006) Anti-amyloidogenic and neuroprotective functions of cathepsin B: implications for Alzheimer's disease. Neuron 51:703-714.

Ognibene E, Middei S, Daniele S, Adriani W, Ghirardi O, Caprioli A, Laviola G (2005) Aspects of spatial memory and behavioral disinhibition in Tg2576 transgenic mice as a model of Alzheimer's disease. Behav Brain Res 156:225-232.

Palop JJ, Jones B, Kekonius L, Chin J, Yu GQ, Raber J, Masliah E, Mucke L (2003) Neuronal depletion of calcium-dependent proteins in the dentate gyrus is tightly linked to Alzheimer's disease-related cognitive deficits. Proc Natl Acad Sci U S A 100:9572-9577.

Palop JJ, Chin J, Mucke L (2006) A network dysfunction perspective on neurodegenerative diseases. Nature 443:768-773.

Palop JJ, Chin J, Roberson ED, Wang J, Thwin MT, Bien-Ly N, Yoo J, Ho KO, Yu GQ, Kreitzer A, Finkbeiner S, Noebels JL, Mucke L (2007) Aberrant excitatory neuronal activity and compensatory remodeling of inhibitory hippocampal circuits in mouse models of Alzheimer's disease. Neuron 55:697-711.

Poirier R, Wolfer DP, Welzl H, Tracy J, Galsworthy MJ, Nitsch RM, Mohajeri MH (2006) Neuronal neprilysin overexpression is associated with attenuation of A $\beta$-related spatial memory deficit. Neurobiol Dis 24:475-483.

Roberson ED, Mucke L (2006) 100 years and counting: prospects for defeating Alzheimer's disease. Science 314:781-784.

Roberson ED, Scearce-Levie K, Palop JJ, Yan F, Cheng IH, Wu T, Gerstein H, Yu GQ, Mucke L (2007) Reducing endogenous tau ameliorates amyloid beta-induced deficits in an Alzheimer's disease mouse model. Science 316:750-754

Rockenstein E, Mante M, Alford M, Adame A, Crews L, Hashimoto M, Esposito L, Mucke L, Masliah E (2005) High $\beta$-secretase activity elicits neurodegeneration in transgenic mice despite reductions in amyloid- $\beta$ levels: implications for the treatment of Alzheimer's disease. J Biol Chem 280:32957-32967.

Rockenstein EM, McConlogue L, Tan H, Power M, Masliah E, Mucke L (1995) Levels and alternative splicing of amyloid $\beta$ protein precursor
(APP) transcripts in brains of transgenic mice and humans with Alzheimer's disease. J Biol Chem 270:28257-28267.

Sakurada C, Yokosawa H, Ishii S-I (1990) The degradation of somatostatin by synaptic membrane of rat hippocampus is initiated by endopeptidase24.11. Peptides 11:287-292.

Selkoe DJ (2001) Clearing the brain's amyloid cobwebs. Neuron 32:177-180.

Shankar GM, Bloodgood BL, Townsend M, Walsh DM, Selkoe DJ, Sabatini BL (2007) Natural oligomers of the Alzheimer amyloid- $\beta$ protein induce reversible synapse loss by modulating an NMDA-type glutamate receptor-dependent signaling pathway. J Neurosci 27:2866-2875.

Shankar GM, Li S, Mehta T, Garcia-Munoz A, Shepardson NE, Smith I, Brett F, Farrell MA, Rowan MJ, Lemere CA, Regan CM, Walsh DM, Sabatini BL, Selkoe DJ (2008) Amyloid $\beta$-protein dimers isolated directly from Alzheimer brains impair synaptic plasticity and memory. Nat Med 14:837-842.

Shirotani K, Tsubuki S, Iwata N, Takaki Y, Harigaya W, Maruyama K, KiryuSeo S, Kiyama H, Iwata H, Tomita T, Iwatsubo T, Saido TC (2001) Neprilysin degrades both amyloid beta peptides 1-40 and 1-42 most rapidly and efficiently among thiorphan- and phosphoramidon-sensitive endopeptidases. J Biol Chem 276:21895-21901.

Solà C, Tusell JM, Serratosa J (1999) Comparative study of the distribution of calmodulin kinase II and calcineurin in the mouse brain. J Neurosci Res $57: 651-662$.

Tagami S, Okochi M, Fukumori A, Jiang J, Yanagida K, Nakayama T, Morihara T, Tanaka T, Kudo T, Takeda M (2008) Processes of beta-amyloid and intracellular cytoplasmic domain generation by presenilin/gammasecretase. Neurodegener Dis 5:160-162.

Townsend M, Shankar GM, Mehta T, Walsh DM, Selkoe DJ (2006) Effects of secreted oligomers of amyloid $\beta$-protein on hippocampal synaptic plasticity: A potent role for trimers. J Physiol 572:477-492.

Tucker HM, Kihiko M, Caldwell JN, Wright S, Kawarabayashi T, Price D, Walker D, Scheff S, McGillis JP, Rydel RE, Estus S (2000) The plasmin system is induced by and degrades amyloid-beta aggregates. J Neurosci 20:3937-3946.

Turner AJ, Isaac RE, Coates D (2001) The neprilysin (NEP) family of zinc metalloendopeptidases: genomics and function. Bioessays 23:261-269.

Van Nostrand WE, Wagner SL, Suzuki M, Choi BH, Farrow JS, Geddes JW, Cotman CW, Cunningham DD (1989) Protease nexin-II, a potent antichymotrypsin, shows identity to amyloid $\beta$-protein precursor. Nature 341:546-549.

Walsh DM, Selkoe DJ (2007) A beta oligomers-a decade of discovery. J Neurochem 101:1172-1184.

Walsh DM, Tseng BP, Rydel RE, Podlisny MB, Selkoe DJ (2000) The oligomerization of amyloid $\beta$-protein begins intracellularly in cells derived from human brain. Biochemistry 39:10831-10839.

Weber P, Metzger D, Chambon P (2001) Temporally controlled targeted somatic mutagenesis in the mouse brain. Eur J Neurosci 14:1777-1783. 